reprints furnished to their authors by the Institute, have in not a few instances merited a more marked distinction, and this the Institute will hereafter be in position to awatd.

The improvement of the Journal during the past year as regards its contents has extended to its typographic quality as well. The changes in this direction, while thorotughgoing and extensive, have yet been studiously made to retain that general appearance of the JouRN Ar. which has characterized it throughout its many years and which has thus, in a way, become a symbol of its stability.

The financial status of the Journal has also improved considerably during the past year. Notwithstanding the additional costs of the publication incurred during this period and, to some extent at least, because of these additions, the income of the publication has overlapped the additional costs and brought it more and more nearly to the point where the cash balance will be that of a surplus instead of a deficit. Evern as it is, counting the accretions to the Library, obtained through exchanges with the Journai, its publication affords a substantial gain, though not yet enough to reasonably requite the efforts for its promotion. Not the least important of these efforts are those of the Actuary of the Institute, whose co-operation in the management of the business affairs of the Publication Committee is greatly appreciated by its members.

Respectfully submitted,

LouIs E. LeEvy,

Chairman.

\title{
REPORT OF THE COMMITTEE ON SECTIONAL ARRANGEMENTS.
}

To the Board of Managers:

During the year ending September 30, 1910, thirty-one meetings were held by the Sections and papers on the following subjects were presented:

Physics and Chemistry Section.

Eight Meetings.

\section{Electrical Section.}

\section{Eight Meetings.}

October I4, I909.

Recent Improvements $i_{\text {.. }}$ the Design of Nernst Lamps.

Mr. Chas. A. Barton.

November 18, rgog.

The Electric Reduction of Tron Ore.

Dr. Jos. W. Richards.
Advances in Electro-Analysis.

Mr. Jacob S. Goldbaum.
November II, 1909.

Mr. Jacob S. Goldbatim.
Voltaic Cells.
Prof. Edward H. Landis.

October 7, Igo9.

Some of the Laws Concerning 
January 20 , I9Io.

Promotion of Safety in the Tiansportation of Explosives and Other Dangerous Articles in the U. S.

Col. B. W. Dunn.

March 3, Igio.

An Analysis of Illumination Requirements in Street Lighting. Mr. Arthur G. Sweet.

March Io, I9Io.

Phennmena of Flocculation and Deflocculation.

Dr. Edward E. Free.

April 7, I9IO.

Chemistry of Colloidal Matter.

Dr. Robt. H. Bradbury.

May 5, rgro.

Flax Growing and Linen Manufacturing in the U. S., 'Present and Future.

Mr. Jas. Wood Pogue.

May I2, I9Io.

Recent Progress in the Chemistry of the Sugars.

Mr. Jos. S. Hepburn.

Mechantcal and Engineering.

Seven Meetings.

October 2I, Igog.

Thrce Centurics of Glass.

Mr. John I. Arbogast.

December 2, Igog.

The Use of Concrete Piles.

Mr. W. F. Hall.
January I3, I9Io.

Methods and Results of Electrical Testing.

Dr. Clayton Sharp.

February Io, I9Io.

Electrical Heating.

Mr. W. S. Hadaway, Jr.

February 17, I9I0.

Electric Railway Signals.

Mr. Carl P. Nachod.

March 24, I9то.

The Electrometallurgy of Steel.

Dr. Jos. W. Richards.

March 3г, Igio.

The Electric Vehicle.

Mr. John Meyer.

April 28, I9זo.

Magnetic Hystercsis in a Rotating Field.

Dr. Morton G. Lloyd.

Photographic Section.

Five Meetings.

October 28, 1909 .

Demonstration of the New Bausch and Lomb Balopticon for the Projection of Lantern Slides, Opaque Objects and Micro-Slides.

Mr. Arthur H. Thomas.

December 9, Igog.

- Infra-Red and Ultra-Violet-a New Departure in Photography.

Dr. Robt. W. Wood. 
December 30, I909.

Flying, the New Art.

Mr. Wilbur R. Kimball.

Januaty 6 , I9Io.

Steel in Freight Car Construction.

Mr. C. A. Seley.

February 3, I9Io.

Modern Heavy Guns.

Mr. Samuel Lichtman.

March I7, IOIO.

A New Pyrometer.

Mr. Chas. E. Foster.
January 27 , I9Io.

The Making of Lantern Slides.

Mr. Chas. R. Pancoast.

February 24, I9Io.

Symposium on Modern Photographic Developers.

Messrs. John Bartlett, Reuben Haines, Alfred Holden, S. Hudson Chapman.

April I4, IgIo.

Unusual Trees.

Mr. J. W. Ridpath.

Photomicrographs in Natural Colors.

Dr. Henry Leffmann.

April 21, I9Io.

Liquid Gas.

Mr. L. Akesson.

Mining and Metallurgical Section.

Three Metings.

November 4, 1909 .

Address of the President of the Section.

Prof. A. E. Outerbridge, Jr.
December 16 , 1909 .

Comparison of Copper and Lead Smelting.

Mr. Hiram W. Hixon.

\section{May ig, roro. \\ Copper Deposits of Franklin- \\ Adams Counties, $\mathrm{Pa}$. \\ Dr. Edgar T. Wherry.}

The attendance at these meetings was much better than during previous years, the average attendance being sixty persons.

It is believed that the subjects presented also proved more interesting than those of previous years. The improvement in attendance and general interest was very marked during the closing months of the year, subsequent to the term embraced in this report.

It is believed that a new stimulus would be given to the work of the sections, if arrangements could be effected to promote co-operative action between the local sections of national scientific and technical associations and the several sections of the Institute, and your committce would suggest that the Board would give authority to the Secretary to use his endeavors towards sectring such co-operation.

Philadelphia, PA., January ir, IgI.

James Christie,

Chairman. 